研究課題評価

1 研究課題名：シャペロニンの役割の解明による効率的なタンパク質折りたたみ法の確立

2 研究者氏名：田口 英樹

3 研究の狙い:

Anfinsen のドグマで知られるように、タンパク質の折れたたみは他からのエネルギ一を必要とし ない自発的に進行するプロセスである。しかし、細胞内の多くのタンパク質の折れたたみにはシャ ペロンが必要である。さらには、必須のシャペロンであるシャペロニン GroEL の場合、ATP の加水 分解まで必要である。はたして、シャペロニンはタンパク質の折れたたみに対していったい何をし ているのであろうか。逆に、シャペロニンに折れたたみが助けられるタンパク質（基質タンパク質） の性質とはどのようなものであろうか。本研究では、シャペロニンと基質タンパク質双方をさまざま な手法で解析し、シャペロニンによるタンパク質折れたたみの全容解明を目指した。

4 研究成果:

（1） シャペロニンの反応サイクル ダブルタイマー機構

大腸菌のシャペロニンはダブルリング構造の GroEL と補助因子 GroES からなる分子量 90 万 におよぶタンパク質複合体である。GroEL は ATP 存在下で大きく構造変化したのちにGroES 之結 合し、大きな空洞を形成する。その空洞には基質となる変性タンパク質が閉じ込められて、その 「ゆりかご」の中で凝集の危険から免れた基質タンパク質は折れたたみを完了することが知られて いる。このシャペロニンの機能 (GroEL と GroES の結合·解離、変性 GFP のシャペロニン空洞内 での折れたたみ)を1分子イメージングで解析し、さらには ATP 加水分解活性の速度論解析など も行った結果、我々は GroEL の反応サイクルは二つの独立したステップが連続して起こる「ダブル タイマーモデル」に従うことを提案した(図1)。

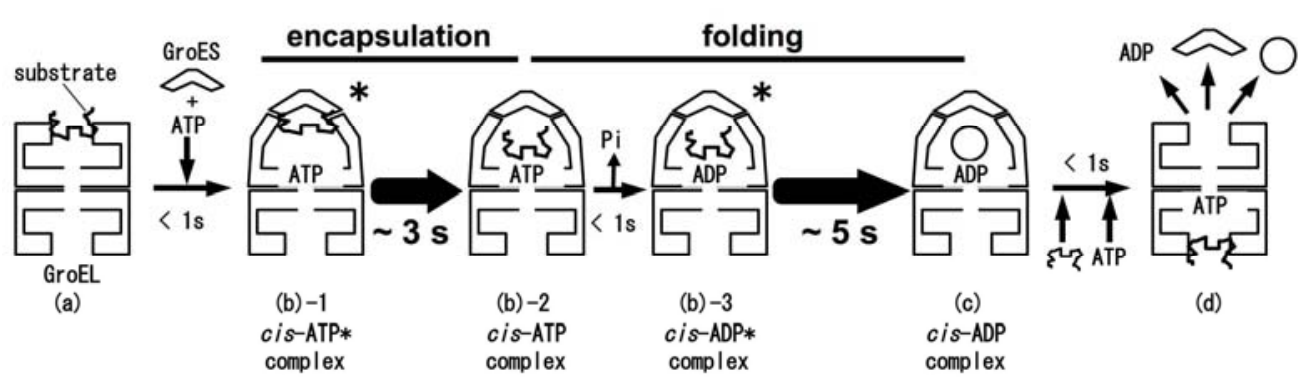

図 1 シャペロニン GroEL-GroES の反応サイクルモデル

また、このサイクルにおいて基質タンパク質がどのように構造変化していくのか調べるために、 シャペロニンの基質としてよく用いられる Rubisco タンパク質に部位特異的に2種類の蛍光色素を 導入して分子内蛍光共鳴エネルギ一解析もおこなった。

（2）基質タンパク質を空洞内に閉じ込めたシャペロニン複合体を用いた研究

(a) 基質タンパク質を閉じ込めたシャペロニン複合体の立体構造

GroEL の ATPase サイクルが変性タンパク質によって大きく加速されること、比較的大きなタン パク質の空洞内での折れたたみはかなり窮屈になることなどから、GroEL 自身が基質タンパク質 の折れたたみに何らかの作用を及ぼしているのではないかと予想されている。まず、基質タンパ ク質を空洞に含んでいる GroEL-GroES 複合体の立体構造はどうなっているのであろうか。好熱 菌の GroEL-GroES 複合体は安定で、精製中も複合体が解離しないので、細胞内でシャペロニン の基質タンパク質を含んだまま精製できる。その立体構造を決定したところ、興味深いことに GroES が結合しているGroEL の頂点ドメインだけが大きく歪んでおり、特徵的な七回対称から大き 
く崩れていることがわかった。X線結晶解析では基質タンパク質の電子密度は見えていないが、 生化学的な解析からは歪みの見えた GroEL リングは基質タンパク質を含んでいるので、基質タン パク質の存在が歪みを生じさせたのではないかと考えている。

（b）in vivo で空洞に入る基質タンパク質の同定

上記の好熱菌 GroEL-GroES 複合体には多くの種類の基質タンパク質が含まれている。そこで プロテオム的な手法で基質タンパク質の同定を行い、シャペロニンの空洞内に入る23種類の基 質蛋白質のリストを作った。

(c) 基質タンパク質を閉じ込めるのに必須の残基

好熱菌 GroEL-GroES 複合体には大腸菌の複合体では見つかっていなかった GroELと GroES の接触部位が存在していた。この接触部位の中の保存された疎水性残基を親水性に置換した GroELをもつ大腸菌は生育できないことから、この残基の重要性が確認できた。また、 in vitroでそ の変異をもつ GroEL は基質タンパク質を GroEL-GroES の空洞内に閉じ込めることができないこと がわかった。

（3）必須因子のみからなる無細胞タンパク質合成系(PURE システム)を用いたシャペロニン GroEL の役割解明

in vitroでGroELがタンパク質の折れたたみを助ける実験では、既に天然構造を取っているタン パク質を尿素や熱などで変性させて用いるので、翻訳後できてきた新生ポリペプチドの折れたた みのようすを調べることはできない。シャペロニンが新生ポリペプチドのフォールデイングの際、ど のようにはたらいているのかを調べるために、最近開発された必須因子からなる無細胞タンパク 質合成系(PURE システム)を用いた。PURE システムは通常用いられる細胞抽出液を用いた無細 胞タンパク質合成系とちがい、シャペロンをまったく含まない。そこで、翻訳の際にGroEL がどのよ うに影響するかを純粋に調べることが可能である。PURE システムでさまざまなタンパク質を翻訳 させたところ、GroEL-GroES があるときに可溶性が大きく上昇するタンパク質が存在した。また、こ れまでは、GroEL は翻訳後に折れたたみを助けると信じられてきたが、我々の結果からは、翻訳 に共役して、つまりリボソームから新生ポリペプチドが解離する前から GroEL は関与して、折れた たみを助けることを見いだした。さらに、PURE システムだけでなく、大腸菌内においても GroEL は 翻訳途中のリボソームに新生ポリペプチドを介して結合していることも見いだした。

\section{5 自己評価}

以上のように本研究により、シャペロニン GroEL の作用機構の理解が大きく深まったと考える。 特に従来あまり顧みられることがなかった基質タンパク質が存在するところで GroEL がどのように はたらくか、構造がどうなっているのかに関して大きな進展があった。

これまで GroEL の研究は in vitro の研究が先行しており、細胞内で実際にどうはたらいているの かは意外なほどわかっていない。本研究で明らかになった空洞内に入る細胞内基質タンパク質の リストや新生タンパク質の折れたたみにおけるシャペロニンの役割は、今後 GroEL が細胞内でど のようにはたらいているかを知るための重要な知見になると考える。

また、本研究では十分に追究できなかったが、折れたたみが非常に困難なタンパク質がなぜシ ヤペロニンの空洞内では折れたたむのかについて今後研究を進めていきたい。シャペロニンがな いと折れたたみが進行しないように見えるタンパク質では、シャペロニンが積極的にタンパク質を 「折りたたんで」いる可能性も示唆されてきている。もし、そうであるならば、シャペロニンはどのよ うな作用を基質タンパク質に及ぼすのであろうか。今後も研究を進めていき、究極的にはシャペロ ニンを有効に用いて効率的なタンパク質折りたたみ法を確立したいと考えている。

6 研究総括の見解

シャペロニン複合体の反応サイクル機構解明や、基質タンパク質が存在する場での GroEL の 役割や構造解明に大きな進展があつた点、評価している。特にシャペロニンの働きをタンパク質 
物性のレベルで考えられるようにしたことは大きな成果といえる。この分野では世界をリードする 研究者であり、今後の研究進展が非常に期待できる。

7 主な論文等:

論文

1. Ueno, T.*, Taguchi, H.*, Tadakuma, H., Yoshida, M., Funatsu, T. [* equally contributed] "GroEL mediates protein folding with a two successive timer mechanism" Mol. Cell 14, 423-434 (2004)

2. Shimamura, T., Koike-Takeshita, A., Yokoyama, K., Masui, R., Murai, N., Yoshida, M., Taguchi $\underline{\mathbf{H}}$., Iwata, S. "Crystal structure of the native chaperonin complex from Thermus thermophilus revealed unexpected asymmetry at the cis-cavity.” Structure 12, 1471-1480 (2004)

3. Taguchi, H., Tsukuda, K., Motojima, F., Koike-Takeshita, A., Yoshida, M. "BeF $F_{x}$ stops chaperonin cycle of GroEL/GroES and generates a complex with double folding chambers” J. Biol. Chem. 279, 45737-45743 (2004)

4. Ying, B.-W. Taguchi, H., Kondo, M., Ueda, T. "Co-translational involvement of the chaperonin GroEL in the folding of newly translated polypeptides" J. Biol. Chem. 280, 12035-12040 (2005)

5. Koike-Takeshita, A, Shimamura, T., Yokoyama, K., Yoshida, M., Taguchi, H. "Leu-309 plays a critical role in the encapsulation of substrate protein into the internal cavity of GroEL. ” $J$. Biol. Chem. 281, 962-967 (2006)

(邦文総説)

1 小池あゆみ、田ロ 英樹 「分子シャペロン」(分担) in タンパク質科学一構造·物性·機能(化 学同人) 291-302 (2005)

2 田口 英樹「シャペロニン GroEL の作用機構: ATP と変性蛋白質の役割」生物物理 印刷 中

3 田ロ 英樹、イン・ベイウェン、上田卓也 「翻訳時のシャペロンのはたらき」タンパク質社会 学 実験医学別冊 23, 2248-2253 (2005)

4. 河田 康志、田口 英樹、吉田 賢右「シャペロニン GroEL の作用機構」 蛋白質核酸酵 素 49, 847-852 (2004)

5. 上野 太郎、田口 英樹「GFP1分子の折れたたみ観察から GroEL の機能を探る」実験 医学 22, 90-91 (2004) 